\title{
And all the worlds will have one start ... (on the semantic load of the lexical unit love in the poetry by A. Tolstoy)
}

\author{
Oleg Voronichev - Natalia Atamanova - Natalia Mospanova - Irina \\ Strekalova
}

DOI: $10.18355 /$ XL.2018.11.02.13

\begin{abstract}
The relevance of this study is determined by the linguists' interest in the language used by the 19th-century Russian poet A. Tolstoy. The semantic and stylistic aspects of the poet's key lexical units and their functioning within his lyrical narrative have not been yet made the subject of a dedicated study. Comparative analysis is the leading method of this study. The original semantics of the lexical unit love occurring throughout the poet's lyrics is being identified against the usual meanings recorded in modern Russian language definition dictionaries and in definition dictionaries reflecting the lexical composition of the Russian language as spoken in the second half of the 19th century. The study identified all the meanings of the word love in A. Tolstoy's lyrics, taking into consideration their possible juxtapositions, semantic expansions, and stylistic gradations. It has been determined that in terms of this study, the word love has a profound, divine and philosophical content attributable to the author's fascination with cosmism that dominated his artistic mindset. The expressive semantic energy contained within the word love creates a push for the transformation of meanings and revelation of additional semantic nuances not only of the adjacent but also of distant words in the context of a poem. The study resulted in a new interpretation of the usage of the lexical unit love in the poet's lyrical narrative used for the relevant entry in the soon-to-be-published A. Tolstoy's Dictionary of Poetic Terms. This material can be used by the researchers of A. Tolstoy's language, philologists, and teachers.
\end{abstract}

Key words: A. Tolstoy, lexical unit, love, author's interpretation, semantics, Russian poetry

\section{Introduction}

Lexico-semantical and lexicographical analyses of the language used by a certain author had been known in the studies of Russian philology since the late 19th century (Grot, 1883), however, they became most productive starting from the middle of the last century, after the necessary theoretical basis for the studies of belles-lettres had been established by V.V. Vinogradov (2000), G.O. Vinokur (1990) and others. Such studies resulted in the compilation of dictionaries of the terms used by various authors: The Shchedrin Dictionary (Olminsky, 1937) and The Dictionaryof Pushkin's Language (Vinogradov, 2000) were followed by The Dictionary of M. Gorky Drama (Bakhmutova, 1994), The Dictionary of Plays by A.N. Ostrovsky (Ashukin, Ozhegov, Filippov, 1993), The Dictionary of M. Tsvetaeva's Poetic Terms (Belyakova, 1996), The V. Shukshin Dictionary (Yelistratov, 2001), The Dictionaryof F.I. Tyutchev's Poetic Terms (Golovanevsky, 2009), The A. Delvig Dictionary (Vasilyev, Zhatkin,2009), The Dostoyevsky Dictionary: Ideoglossary (Karaulov, Ruzhitsky, Ginzburg, 2008; Karaulov, 2001) and others.

In this context, special features of the language used by particular authors are studied in various scopes - from examining an individual piece of poetry or prose, a thematic cycle of such pieces, separate thematic or semantic groups, grammatical categories of the author's texts, working out concrete statistics of the author's texts, to endeavors to offer the most comprehensive idea - based on all the works by the author - about the language characteristic of a particular author or a literary school. 
This year is the 200th anniversary of A.K. Tolstoy - a prominent Russian poet, novelist, and playwright. The researchers' enthusiasm for his artistic mastery of words has long been artificially restricted in Russia, especially during the times dominated by the cult of personality. The author was called - in a simplistic, sociologically vulgar manner - an adept of the "pure art" theory, in view of which his works were labeled "decadent literature" (Petrov, 1961).

That said, the fine language of A.K. Tolstoy's works, the topicality of his ideas, his unique, imaginative flair, and semantic profundity deserve most focused attention from philologists.

As of today, no effort has been put into the detailed study and description of the lexical and semantic aspects of A.K. Tolstoy's poetic language. At the same time, since A.K. Tolstoy possessed "his own, original and at the same time very versatile personality; he used to effortlessly and skillfully demonstrate the command of his mother tongue" (Turgenev, 1999), his idiolect is certainly worth of careful study and lexicographical representation. It has long been necessary to create the dictionary of the author's poetic terms intended to offer the most comprehensive depiction of the semantic features of the author's individual style, such as his individual usage of words and ambiguity, including the juxtaposition and expansion of meanings.

Therefore, the purpose of this paper is to identify all possible meanings of the lexical unit love in A.K. Tolstoy's lyrical narrative.

Objectives of the study: to reveal the usual meanings of the lexical unit love as recorded in modern Russian language definition dictionaries and in definition dictionaries reflecting the lexical composition of the Russian language that used to be spoken in the second half of the 19th century; to spot possible juxtapositions of the meanings of the lexical unit; semantic expansions and stylistic nuances of the lexical unit in A.K. Tolstoy's poetry attributable to the poet's view of the world; to compile an entry for the word love in the soon-to-be-published Dictionary of Poetic Termsof A.K. Tolstoy.

\section{Literature Review}

The recent years have seen a growing interest towards the semantic features of the languages used in the works by prominent authors of prose and poetry of different styles and genres, which is supported by the newest research on authorial lexicography, linguopoetics and linguostylistics (Fegley, Vetle, 2012; O'Neill, 2013; Murillo, 2013; Stewart, 2014a; Stewart, 2014b; Wang, 2014; Alexopoulos, Manolis, 2015; Richardson, 2015; Miller, 2015; Kaup, 2013; Klaus, 2016; Williams, 2016; Bandhakavi et al., 2017; Abdullahi, 2017).

\section{Methodology}

Among the research methods employed in the study were the descriptive method, methods of semantic and component analysis, linguostylistic analysis, and elements of statistical analysis.

The descriptive method consists in the gathering and systemizing of language material, characterizing its content and structure, as well as describing the functional, linguistic and semantic features of the studied material.

The semantic and component methods were used by the authors to undertake the language-specific analysis of lexical units in terms of their content and meaning in the poetic context.

The methods of linguostylistic analysis involve choosing various techniques for analyzing poetry from the perspectives of traditional and the author's individual stylistics.

The statistical analysis method intends to establish the numerical characteristics and functional relations between the lexical units, which can be derived from the

XLinguae, Volume 11, Issue 2, April 2018, ISSN 1337-8384, eISSN 2453-711X 
continuous sampling of these units from poetic contexts and the calculation of unit frequencies in a concrete poetical system.

\section{Results}

In A.K. Tolstoy'spoetry $(1981 ; 1984 ; 1988 ; 2011 ; 2012)$, love is among the lexical units with the highest frequency. In his lyrics alone, there are 81 occurrences of this word in various forms and meanings.

By analyzing the entry "love" in the modern Russian language definition dictionaries, it was possible to identify the following usual meanings of this lexical unit:

1.The feeling of profound affection towards someone or something.

2. The feeling of ardent cordial partiality, emotional appetency for a person of the opposite sex.

3.Internal striving, longing, inclination, gravitation towards something.

One can find such meaning in all dictionaries: Small Academic Dictionary 2 (Yevgenyeva, 1999), Great Academic Dictionary (Chernyshev, 1965), Explanatory Dictionary of the Russian Language (Ushakov, 2009), etc.

The widest range of meanings of the lexical unit love (6 lexical semantic definitions) can be found in the Dictionary of the Russian Language by S.I. Ozhegov and N.Y. Shvedova (2006) (DOS) and the Modern Dictionary of the Russian Language by T.F. Yefremova (2006).

Apart from the aforementioned lexical semantic definitions, D.N. Ushakov (2009) offers a colloquial metonymical meaning of "a person inspiring the feeling of love."

Compared to the meaning offered by V.I. Chernyshev (1965), A.P. Yevgenyeva (1999), and D.N. Ushakov (2009), the entry in S.I. Ozhegov and N.Y. Shvedova (2006) added another colloquial meaning used in the context of making love; meanwhile, the definition placed on the third position in V.I. Chernyshev (1965), A.P. Yevgenyeva (1999), and D.N. Ushakov (2009), the entry in S.I. Ozhegov and N.U. Shvedova (2006) added another colloquial meaning used in the ("Internal striving, longing, inclination, gravitation towards something") and on the fourth position in D.N. Ushakov (2009), is essentially split into two independent lexical semantic definitions in S.I. Ozhegov and N.Y. Shvedova (2006), with the two core semes of "inclination" and "taste." As opposite to S.I. Ozhegov and N.Y. Shvedova (2006), T.F. Yefremova (2006) does not contain the colloquial definition, instead the author splits the definition "mutual sexual desire" into two ones, based on the key semes "feeling" and "relationship."

In A.K. Tolstoy's lyrical discourse, the lexical unit love implements some of these meanings. For example, the feeling of profound affection, sincere and selfless attachment to someone.But his heart is burning with love for his brethren, He is full of animosity for violence (Tolstoy, 1981); the feeling of cordial partiality, appetency for a person of the opposite sex. And thus addressing her, Harald says, with love in his shining look... (Tolstoy, 2012); internal striving, longing, inclination, gravitation towards something. Urged by his love for sciences, he leaves his family to travel to the city on his feet (Tolstoy, 1988); colloquial. A person for whom a person of the opposite sex experiences a feeling of deep emotional desire. And so I am recalling my each reproach, // And I keep repeating each amiable word, that I could have told you, my love, yet grimly buried inside my heart (Tolstoy, 2012) and so on.

The most vivid interest is inspired by the author's individual meanings of the lexical unit love in A.K. Tolstoy's verses. Here the word "love" has a divine, philosophical meaning and is characterized by the author's individual attitude:

1) The divine origin, fundamental principle;

2) The internal creative energy of the universe;

3) The ideal image of the world;

4) The harmony, reasonability of existence;

5) The eternal essence determining the cosmic cycle. 
The author also introduces the following meanings: protection of God, Holy Mother, and Saints, their mercy, benevolence towards people and the people's willing to worship God or gods. Blessed hierarchs in golden covers look up to them, full of love (Tolstoy, 1984); Burning with love for his neighbors, He [Christ] taught the people humbleness, He subjected all Moses' laws to the law of Love (Tolstoy, 1984); veneration of the rule of the tsar as the Lord's Anointed, submission to his power. His appearance filled them all with love and awe, as Monomakh's Cap was shining on his forehead (Tolstoy, 1984).

6) Some verses demonstrate the juxtaposition of the usual and the author's meanings, such as: the feeling of profound affection towards someone or something + the divine origin, fundamental principle and internal creative energy of the Universe and everything that exists in it. Having merged into single love, we are now a common link of the endless chain, // And it is now our destiny that will not let us fall apart on our way up to the shining of the eternal truth (Tolstoy, 1984).

The semantic energy of the noun love in the poetic texts by A.K. Tolstoy inevitably transforms the meanings of all significant words.

\section{Discussion}

The greatest interest is attached to the identification of semantic and stylistic aspects of the author's usage of the lexical unit love.

In the opinion of the authors of this paper, the most exemplary poem in this context is the one called "I, who raised from the darkness and dust..." Let us examine certain aspects of the lexical unit love in this poem.

The poem "I, who rose from the darkness and dust..." (1851-1852), written mostly in the genre of philosophical lyrics, embraces the genuine emotional intensity intrinsic to all lyrical works by A.K. Tolstoy. It bears a certain similarity to Pushkin's The Prophet. However, according to A.K. Tolstoy, "the wings of love - they raise you up (as Seraph descends!) to the home land of fire and words." Here, in this text, everything presents contrast: below (dust and darkness) and above (fire and words), indignity and grace, smallness and greatness. The keyword transcending this polarity is love - as it can raise you up and transform. In addition to that, this transformation is effortless and joyful - rather than the formidable, bloody operation in The Prophet (Koshemchuk, 1998).

If we draw upon the well-known quotation by A. Blok (2009), "Every poem is a veil stretched on the points of few words. Those words shine like stars. They are the reason the poem exists for." (Blok, 1971), which precisely and graphically pinpointed the role of keywords in a literary text, then, in the line of developing on this metaphor, it bears mentioning that such "star words" in a poem can be quite different by their brightness level. For instance, it is obvious that the "first magnitude star" in the poetic work in question is the word love. A.K. Tolstoy's verse sings a hymn to love in its supreme, "cosmic" meaning. It is specifically that word, building upon new expansions of its meaning throughout the text, which acquires in the closing stanza its sublime, divine and cosmic semantics, while imparting additional, author's individual semantic shades to other words in the text, i.e. also becomes a sort of the origin of "all worlds" - a starting push, and impulse of a kind of chain reaction causing the alteration and enrichment of the meanings of other lexical units interacting in this context.

Within a relatively short poetic text, Tolstoy uses the word love seven times. Considering the author's belief in the magic of numbers, one can assume that this number is by no means random. It is well known that the number 7 is considered in both numerology and world culture a divine, lucky number, one of the mystical parameters of the universe. It is also obvious that in this and other, thematically close poems by Tolstoy, the word love is presented in the author's own - biblical and

XLinguae, Volume 11, Issue 2, April 2018, ISSN 1337-8384, eISSN 2453-711X 
philosophically cosmic at the same time - meaning of "the divine origin, fundamental principle and internal creative energy of the Universe and everything that exists in it." It is worth noting that such interpretation was rather more appropriate of Tolstoy's coevals than of people living in the 21 st century. Cf. the entry in Dal's dictionary: while it offers a very concise and "down-to-earth" interpretation of the lexical unit love in all its meanings, in a way similar to our modern definition dictionaries ("the state of someone who loves, passion, cordial attachment, inclination; lust; liking, favor of something" (Dal, 2007), still the usage examples closest to its definition can to some extent prove that the people of the 19th century used to load the word love with somewhat different, more sublime meaning: "God's love is limitless. The marriage of truth and love gives birth to wisdom. Conquer hearts with love and not fear. God's love is no match to that of a man. A man's love cares for the man himself, while God's love cares for a friend. There is no love better than to sacrifice your soul for a friend. Where love is, God is" (Dal, 2007), and so on. A significant contribution to what has been said on the understanding of the essence of love by progressive minds in the pre-Revolution Russia was offered by V.S. Solovyov (1896) in the fragment of his article Love in the F.A. Brockhaus and I.A. Efron (2011) Encyclopedic Dictionary (2011), "As early as in the prophetic books of the Old Testament, the relationship between God and his chosen people is depicted mainly as a marriage (and thus the people's apostasy from its God is perceived as nothing short of adultery). In the New Testament, this idea is carried over to Christ and the Church, and the story finale is depicted as the marriage of the "Holy Lamb" to His fiancée the enlightened and glorified Church of "New Jerusalem." Therefore, according to Christian beliefs, the perfect origin of social relations is not power, but love" (Solovyov, 1896). By contrast, the four-volume Dictionary of the Church Slavonic and Russian Language of the Imperial Academy of Sciences reflecting the lexical composition of the language used in the times of A. Tolstoy, offers a brief description of only one of then known and relevant meanings of the lexical unit love, namely "Cordial affection towards someone" (DCSRL, 1847).

In the sixth stanza of "I, who raised from the darkness and dust..." that reads, "And my prophetic heart told me // That everything born of the Word, // Pouring out the beams of love, Longs to get back to where it came from," - the lexical unit Word, written with a capital letter, serves as a contextual synonym of the lexical unit love, for which reason, in the authors' opinion, it is the second by significance keyword/key concept in the text structure. For A.K. Tolstoy, as well as for any Russian Orthodox, the concepts Word, God and Love are naturally synonyms and can already be likened in one's perception based on the synthetic link of popular statements from the New Testament, "In the beginning was the Word, and the Word was with God, and the Word was God." (John 1:1) and "God is love. Whoever lives in love lives in God, and God in them." (John 4:16). The first verse of the Gospel of John points to the objective existence of super-temporal and super-spatial, ideal substance - God's Word (Logos) as the origin of everything that exists in the Universe. This verse indicates the existential connection between God's Word and the first hypostasis of the Holy Trinity - the hypostasis of Father, and allows considering the Word one of God's names, while his other name, as it appears from the First Epistle of John, is to be the word Love. All of this organically fits into cosmism - a philosophical paradigm that "relies on the knowledge about the Cosmos and the image of a human as a "citizen of the World" (the cynics, the stoics, Kant, Mamardashvili), as well as about the microcosm similar to the Macrocosm" (Gritsanov, 2003). Despite the fact that this special theoretical, spiritual phenomenon only occurred in Russia in the late 19th to early 20th centuries, the history of the development of human thought knows many objective premises (views of Pythagoras, Plato, Heraclitus, N. Copernicus and G. Bruno, Kabbalah, the Kant-Laplace nebular hypothesis about the origin of the solar system, etc.) for the emergence of both this school of thought and the corresponding 
worldview, the "cosmic mindset," that to a great extent was also intrinsic to A.K. Tolstoy. The Russian cosmism can be subdivided into five major schools:

1. Natural Science Cosmism.

2. Religious and philosophical cosmism.

3. Artistic and poetical cosmism.

4. Esoteric cosmism.

5. Noospheric cosmism (Maslin, 2014).

Based on the text of "I, who raised from the darkness and dust..." and the organization of linguistic means in his other works similar to this one by the persona's emotional upheaval, as well as by ideological and philosophical topics, and in many respects reflecting the specifics of A.K. Tolstoy's artistic worldview, one can likely believe that this worldview meets the definition of esoteric cosmism, in particular, Agni Yoga (or the Living Ethics as taught by Nicholas and Helena Roerich), of which one of the postulates proclaims the creative power of fire, the fiery energy of thought as the origin and the driving force of everything that exists in the Universe. The sources of the esoteric view of the world can probably be found in Heraclitus' teaching about fire as the fundamental source of matter. The metaphorical expression "home land of fire and words" A.K. Tolstoy used in the fourth stanza also organically fits into this concept as a periphrastic name of the Cosmos, the cosmic highness and depth of the thought (=God's Word) whose energy created and still permeates the entire universe (=all the worlds). In the context of this poem, this fiery energy is epitomized by love.

These ideas possibly resonate with the philosophical and lyrical contemplations of F.I. Tyutchev (1987) in the poem "Nature is not as you imagine her" (1836), with some indication of the influence F.I. Tyutchev (1987) exerted on A.K. Tolstoy. There is no denying that A.K. Tolstoy was aware of this work and could be impressed by it. However, upon close inspection of both poems, it becomes clear that each had its own thematic, ideological and philosophical vector. F.I. Tyutchev (1987) set it out quite clearly in the very first stanza: "Nature is not as you imagine her: // She's not a mold, nor yet a soulless mask - // She is made up of soul and freedom, // She is made up of love and speech" (Tyutchev, 1987). These and the following lines bear the influence of the physico-philosophical views of Friedrich Schelling. Schelling's romantic metaphysics, his idea of animated nature in line with hylozoism - a philosophical point of view claiming that all objects, space, matter, and nature have souls (Gritsanov, 2003) - rather than being artistically implemented in F.I. Tyutchev'S (1987) poem, was expanded and further developed; the Russian poet does not just borrow the thoughts of the German philosopher and offer his creative interpretation thereof, instead he uses them as a foundation for expressing his own perception of the link between humans and nature, the Universe. This perception, as can be seen from this and other poems on similar topics, is idealized to the point when he spiritualizes the Cosmos and the concept of the World Soul. This definitely reminds the cosmisminspired ideas of A.K. Tolstoy. Yet A.K. Tolstoy's cosmism is different - not quite physico-philosophical, but rather philosophical with divine interpretation. F.I. Tyutchev (1987) endues nature not only with love but also with other interrelated and at the same time differentiated by the poet concepts of the same logical sequence soul, freedom, speech. On the other hand, A.K. Tolstoy believes that only Love (that is God, that is the Word) is the only existing, indissociable fundamental basis of the universe, the omnificent and omnipresent energy, the soul of the Universe, the original reason and essence of the world harmony. For that reason, the definition of the second meaning of the lexical unit love provided by A.L. Golovanevsky (2009).The objectively existing, abstract phenomenon of living nature reflected in moral relations, feelings, beliefs (Golovanevsky, 2009) and illustrated by many examples, such as "Nature is not as you imagine her", is dramatically different from

XLinguae, Volume 11, Issue 2, April 2018, ISSN 1337-8384, eISSN 2453-711X 
A.K. Tolstoy's aforementioned interpretation of the word love in the poem "I, who raised from the darkness and dust.."

Other lines in that text can also lend evidence to the fact that A.K. Tolstoy's consciousness formed exactly that perfect image of the world based on love and existing by virtue of its fiery, omnipresent creative energy.

Thus, in the stanza "My dim sight cleared then, // And I could see the invisible world, // And my ears can since hear, // What others cannot sense" and in the following three stanzas, A.K. Tolstoy provides an enthusiastic and picturesque description of what can be revealed to the eyes of a man who learned the blessing of true (cosmic) love and could behold and appreciate the creative power, the internal energy it radiates, the harmony that fills all seemingly customary objects of the world around him.

In the sixth and seventh stanzas, the poet rises up to a metaphorical, philosophical interpretation of the supreme, the most rational and humane existence mechanism of the Universe based on and imbued with love. In fact, A.K. Tolstoy discovers and formulates the "law of conservation of love energy through time and space;" radiated by God (the Word, Logos) and at the same time being one of His hypostases, love is evenly distributed across the Universe, it penetrates each living and inanimate object and, having filled them with harmony and reasonableness of existence, does not just vanish at the end of its heaven-defined time, but returns to its origin, as if closing the cosmic link, and then conceives new lives, thus eternally continuing its creative circulation.

In the closing stanza "Sound and light everywhere, // And a single origin to all the worlds, // As there is nothing in the nature, // That would not be breathing love," the lexical unit love used by the poet in the fourth line and replaced in the second line with a contextual synonymic phrase "a single origin" receives its final, exhaustive, author-defined semantic content, which was formulated earlier in the paper, and at the same time gives new semantic notes to the adjacent words. Thus, it becomes clear that both nouns sound and light acquire in this context an additional seme "harmony," as in the harmony of sounds and the harmony of light colors, shimmers, beams; by "all the worlds" one should also mean the parts of the Universe (Macrocosm), such as planets, nebulae, galaxies, and metagalaxies, as well as the lives and souls of individual people as microcosms and any God's creation, such as an animal, plant, geographical object, etc. In the last two lines, the gerund breathing also attains the metaphorical, contextual semantics "being imbued, filled with the harmony of love; living, existing thanks to the inner love energy."

As was mentioned earlier, the semantic energy of the noun love in the context of the poem "I, who raised from the darkness and dust..." will one way or another transform the meaning of all significant words. Accordingly, the author's individual contextual interpretation of each of them must be analyzed, above all, with this tendency in mind. Indeed, it becomes clear that, for example, in the first two lines, "I, who raised from the darkness and dust // Where I have been dragging on in shackles...",the dictionary semantics of the noun darkness is aligned with the author's definition of "ignorance, being unable to see the true light (= the light of love)"; the noun dust was used in the metaphorical meaning of "the dust of life: wordly vanity; the little nothings of life that do not matter compared to the light of the truth (=love) and even prevent one from cognizing it;" the gerund dragging (derived from to drag) combined with the noun shackles incorporates two meanings of the infinitive form of the verb: the explicit one (to "drag, pull someone or something behind without raising them from the surface of something" (Yefremova, 2006) and the preferred figurative one used in the set phrase "drag on a wretched existence," i.e. to "live a joyless life in poverty, to live a life full of misfortunes" (Ushakov, 2009). However, in the context of the analyzed poem, this semantics also goes through some important changes: to A.K. Tolstoy, dragging on a wretched existence means living without true love, without seeing its omnipresent, invigorating light or recognizing its sublime creative purpose, significance. 
Consequently, the noun shackles in this context also acquires the author's metaphorical content, "soul-degrading, mortal existence on earth, devoid of the light of true (Divine, cosmic) love."

The same or similar individual semantic content of the lexical unit love is characteristic of A.K. Tolstoy's lyrics in general. For example, in the poem "A tear glimmers in your jealous glare..." (1858), the poet hails the cosmic heights of the love to a woman as a feeling that forever binds together the immortal souls of the two people in love. He feels constrained by the "shores of life", his love is as broad "as the sea," i.e. it spans indefinitely across time and space; and after "the earthly woes are over" (i.e. the short, mortal earthly life passes, during which every object of the world around us is subject to "our fragmented love," as we are unable to raise our souls to the heights where we could fathom the universality and pervasiveness of love), the time comes for the coveted supreme and endless (cosmic) phase (hypostasis), to which eventually all loving souls will ascend and in which they, having retained the "glow of eternal beauty", will come back to their Divine Origin, i.e. merge "Into single love, as broad as the sea, // Which no earthly shores can contain!". Another part of the text that explicitly resonates with the poem analyzed here, highlighting the divine, cosmic image of the world that had formed in the poet's consciousness, is the second stanza where the capitalized term Word (compare with the Word in the New Testament and in the studied text by Tolstoy) serves as yet another synonymic name of God, "When the creative power of the Word // Called out the hosts of worlds in the night, // Their love illuminated everything like the sun, // Yet here, on earth, its light // Only casts rare, isolated beams."

The same vector of the poet's visual thinking can be traced down in his poems "Oh, do not rush where life is more cheerful and pure..." (1858), compare: "Having merged into single love, we are now // A common link of the endless chain, // And it is now our destiny that will not let us fall apart// On our way up to the shining of the eternal truth"; "Judging me quite strictly..." (to I. Aksakov, 1859), compare: "But no, in each rustle of a plant // And in each flutter of a leaf // One can hear a different meaning, // Behold different beauty! // I listen to a different voice that comes from them // And, breathing a mortal life, // I look down to earth with love, // But my soul cries out to reach higher." The same meaning in large measure helps the author express his ideas in the poems "God, while preparing me to the battle...", "I have known you, the holy beliefs...", "Raphael's Madonna", "But the maiden had other delights", "John of Damascus;" it is tightly interconnected (on the principle of "gluing together" (Zaliznyak, 2006) with the primary one, "Deep emotional attraction, powerful feeling towards a person of the opposite sex," in the stanza "And all my thoughts, my life, my blood, // The pulsation of each vein in my body // I will devote with pleasure to the one, // Whose endearing image // Will fill me with sacred love // Until I am buried" ("I believe in pure love..."), as well as with another meaning found in the dictionary, "The feeling of profound affection, sincere and selfless attachment to someone", in the lines, "Hear me, oh God, on my deathbed, // My tongue is getting numb and my eyes are betting dim, // But love and forgiveness are in my heart - // So pardon my sins!" (Tolstoy, 1988).Even in the stanza of the textbook poem "My bluebells" written in the late 1840s that goes, "His appearance filled them all // With love and awe, // As Monomakh's Cap // Was shining on his forehead" (Tolstoy, 1981), where the poet foresees and hails the advent of a new tsar capable of reviving the traditions of the pre-Mongol Rus, do good to his people and bring the country to prosperity - even there the word love has a meaning with the same semantic note, as the Orthodox Tsar - the Lord's Anointed and, therefore, the carrier and source of sublime, divine, cosmic energy of love for his subjects.

XLinguae, Volume 11, Issue 2, April 2018, ISSN 1337-8384, eISSN 2453-711X 
Through the analysis of the key lexical unit love, it was possible to create a dictionary entry that interprets this unit in the poet's verses. Such initiatives (the compilation of authors' language dictionaries) are part of an old tradition.

The typology of a dictionary is determined by its goals and purposes. However, even the preparation of dictionaries of the same type (for instance, dictionaries describing poets' lexicons used in lyrical narratives) may raise some controversial points, such as a certain degree of subjectivity in the interpretation of a word, presentation of a system of stylistic markings, the need to specify all word forms and grammatical categories, fixed phrases, etc.

\section{Conclusion}

As part of their research, the authors referred to the Russian language definition dictionaries to find out all the usual meanings of the lexical unit love (there are six core meanings in total). Most of these meanings are identical across different dictionaries.

The analysis of A.K. Tolstoy's lyrical narrative helped identify the following:

- the cases of the juxtaposition of these meanings (those are mainly the cases of juxtaposed usual meanings "the feeling of profound affection towards someone or something", or "the feeling of ardent cordial partiality, emotional appetency for a person of the opposite sex", or the author's "the divine origin, fundamental principle and internal creative energy of the Universe and everything that exists in it"),

- the author's individual usage of the word love associated, above all, with its divine and philosophical content.

This helped the authors realize how interesting, deep and original the semantics of the high-frequency lexical unit love is throughout A.K. Tolstoy's lyrics. In the context of the poet's works, the keyword "love" juices up the surrounding lexical units with its powerful, expressive energy, pushing their meanings, thanks to the author's expansion of concepts, up to truly cosmic heights. Another reason to admire A.K. Tolstoy is the fact that back in the middle of the $19^{\text {th }}$ century, he could not have known a thing about philosophical cosmism, including its esoteric version, yet he was able to think in relevant terms - all thanks to that invigorating energy of love towards "all the worlds," e.g. the home country, a woman, people, nature, etc.

The study resulted in a comprehensive entry for the term love in The A.K. Tolstoy's Dictionary of Poetic Terms. The entry was compiled with due consideration for all usual and authorial interpretations and semantic nuances in various contexts of A.K. Tolstoy's poetic narrative:

love (81) 1. Deep emotional appetency, a power feeling for a person of the opposite sex. Without realizing it, you love him because he is your first love $<88>$; Then, in response for my love, you lowered your eyelids.<108>; And thus addressing her, Harald says, with love in his shining look... (Tolstoy, 2012); Suddenly it occurred to me that she was not completely insensitive to my love, and that there was no sign of ridicule in her look down from the canvas (the main meaning is complemented by the author's semantic shade of the "love for the portrait of a fair lady") $<146>$; $<22>$, $\langle 42\rangle,\langle 54\rangle,\langle 70\rangle,\langle 107\rangle,\langle 161\rangle,\langle 138\rangle,\langle 143\rangle,\langle 145\rangle,\langle 148\rangle,\langle 183\rangle,\langle 231\rangle$, $<240>,<255>,<256>,<257>,<301>$. $\diamond$ The winged god of love. Amor (or Cupid) the god of love in Roman mythology (also known as Eros in Greek mythology); he was pictured with wings, holding a bow and arrows. The winged god of love, stooping over his plough, follows the open furrow like a husbandman $<249>$. $\diamond$ To burn with love. To be besotted with a passion for a person of the opposite sex. She is a nonpareil beauty, he looks are lovely, and many a fine bard are burning with love for her<172>; Malania is burning with love for you, so how come, Boris, that you have different feelings for her? <240>; Smiling from the heaven, the crescent is burning with quiet love for her $[$ Lily $=$ a lily] $<261>$. $\diamond$ Venal love. Sexual services. Anyone can buy her venal love for gold<143>. 2. Colloquial. A person for whom a person of the opposite 
sex experiences a feeling of deep emotional desire.And so I am recalling my each reproach, and I keep repeating each amiable word, that I could have told you, my love, yet grimly buried inside my heart<102>. 3. The feeling of profound affection, sincere and selfless attachment to someone. But his heart is burning with love for his brethren, He is full of animosity for violence<305>; He used to dwell with me at my workshop, and now, after the battle, he found me, still full of loving care for me<147>; But out of love for his children, he divided his land $<178>$. 4. Strong inclination, fondness, passion for something. ...You picked scarlet briar berries and put it lovingly around the unkempt mane of the creamy horse $\langle 50\rangle$; Urged by his love for sciences, he leaves his family to travel to the city on his feet $<117>.5$. The divine origin, fundamental principle and internal creative energy of the Universe and everything that exists in it. Sound and light everywhere, and a single origin to all the worlds, as there is nothing in the nature, that would not be breathing love $<18>$; When the creative power of the Word called out the hosts of worlds in the night, their love illuminated everything like the sun, yet here, on earth, its light only casts rare, separate beams $\langle 78>$; Bending over young Christ, Mary blessed him, and her heavenly love outshone her worldly beauty $\langle 81\rangle$; Be the only one to shine, oh, heavenly love, like a resplendent star through my night! <144>; And she beheld in her youthful delight, soaring high like a prayer in the endless space, the landless sea of fathomless love $\langle 314\rangle$; $\langle 41\rangle,\langle 79\rangle,\langle 101\rangle$. 6. Protection of God, Holy Mother, and Saints, their mercy, benevolence towards people and the people's willing to worship God or gods. Blessed hierarchs in golden covers look up to them, full of love $\langle 116\rangle$; Burning with love for his neighbors, He [Christ] taught the people humbleness, He subjected all Moses' laws to the law of Love $<143>$; He, who with his eternal love would return good for evil, is beaten up, covered in blood, with a crown of thorns on his head. He blessed with his sign all those who suffered as he, who were ill-starred, oppressed and humiliated $<144>$; But waking out from our initial fear, we could not find in ourselves the love we used to feel for him, and so we scattered, pondering, across the meadow and said, "Off you swim, the oaken god who did not save Rugia from peril! Off you swim!" $<133>$. 7. Veneration of the rule of the tsar as the Lord's Anointed, submission to his power. His appearance filled them all with love and awe, as Monomakh's Cap was shining on his forehead $<10>$. 8. The juxtaposition of the $1^{\text {st }}$ and $5^{\text {th }}$ meanings. And all my thoughts, my life, my blood, the pulsation of each vein in my body I will devote with pleasure to the one, whose endearing image will fill me with sacred love until I am buried<293>; Having merged into single love, we are now a common link of the endless chain, and it is now our destiny that will not let us fall apart on our way up to the shining of the eternal truth $\langle 80\rangle$. 9. The juxtaposition of the $3^{\text {rd }}$ and $5^{\text {th }}$ meanings. Hear me, oh God, on my deathbed, my tongue is getting numb and my eyes are betting dim, but love and forgiveness are in my heart - so pardon my sins! $<114>$.

Notes: 1 . The angle brackets contain the identification numbers of the lyrical texts that were part of the $1^{\text {st }}$ volume of the complete (two-volume) set of poems by A.K. Tolstoy (1984).

2. The most exemplary illustrations to this meaning are followed by just identification numbers of the poems where the lexical unit is used with the same lexical and semantical load.

There is a potential for the further research of the poetic language used by the greatest master of words A.K. Tolstoy, in particular:

1) the research on the semantic features of the poetic idiolect of A. Tolstoy, the Russian post-Pushkin classical author, whose works, on the one hand, intrinsically reflect the norms of the Russian literary language of 1840-70s, and on the other hand, reveal semantic, stylistic, ideological and etymological potential of words in poetics;

XLinguae, Volume 11, Issue 2, April 2018, ISSN 1337-8384, eISSN 2453-711X 
2) the research on lexical and semantic aspects of A.K. Tolstoy's poetic language that involves studying all meanings (up to individual semantic nuances) of high-frequency words, including juxtaposed lexical and semantic units, as well as meanings stylistically marked as characteristic of the author;

3 ) the identification of groups of words from the poet's lexicon that are loaded with the author's individual meanings or with certain semantics that can be considered ambiguous;

4) the compilation of The A.K. Tolstoy's Dictionary of Poetic Terms, extension of the theoretical and methodological base and contribution to the corpus of the author's lexicography.

The studies of A.K. Tolstoy's poetic language aim to continue the scientific comprehension of the specifics of the language used by various writers, true genii loci, whose lives and creative works were associated with the Bryansk Region.

The principles of analysis and the conclusions drawn in the course of the study can be used both theoretically, for the further studies of the semantics of A.K. Tolstoy's poetic language and its lexicographical representation, and practically, as part of the teaching of linguistic disciplines, above all lexicology, semantics, poetic semantics.

\section{Bibliographic references}

ABDULLAHI, K.A. 2017.Poetic Style and Social Commitment in NiyiOsundare's Songs of the Marketplace. In: Human and Social Studies, vol. 6, n. 2, pp. 73-83. ISSN 2285-5920.

ALEXOPOULOS, P. - MANOLIS, W. 2015. Creating domain-specific semantic lexicons for aspect-based sentiment analysis.Institute of Electrical and Electronics Engineers.Proceedings of the 10th International Workshop on Semantic and Social Media Adaptation and Personalization. ISBN: 978-1-4673-8395-0.

ASHUKIN, N.S. - OZHEGOV, S.I. - FILIPPOV, V.A. 1993. Dictionary of A. Ostrovsky Plays. Moscow: Vesta. ISBN: 5-86155-009-3.

BANDHAKAVI, A. - WIRATUNGA, N. - MASSIE, S. - PADMANABHAN, D. 2017. Lexicon Generation for Emotion Detection from Text. In: IEEE Intelligent Systems, vol. 32, n. 1, pp. 102-108. ISSN: 1541-1672.

BELYAKOVA I.Yu. 1996. Dictionary of Poetic Terms. Moscow: The Marina Tsvetaeva Memorial House. ISBN, 5787300289.

BLOK, A. 2009. From notebooks and diaries of the period. Ideas from May. Moscow: Terra. ISBN: 978-5-275-01884-4.

BROCKHAUS, F.A. - EFRON, I.A. 2011. The Brockhaus and Efron Encyclopedic Dictionary. Moscow: Knigapotrebovaniyu. ISBN: 978-5-4475-0110-5.

CHERNYSHEV, V.I. 1965. The Dictionary of the Modern Russian Literary Language: in 17 volumes. Leningrad: Academy of Sciences of the USSR.

DAL, V.I. 2007. The Explanatory Dictionary of the Living Great Russian Language. Moscow: AST. ISBN: 5-17-041085-9.

Bakhmutova, N.I. 1994. Dictionary of M. Gorky's Drama: "Somov and others"; "YegorBulychov and others"; "Dostigayev and others". Saratov: The Saratov University Press. ISBN 5-292-01831-7.

DCSRL, 1847. Dictionary of the Church Slavonic and Russian Language compiled by the Second Department of the Imperial Academy of Sciences. Saint Petersburg: The Imperial Academy of Sciences Typography. ISBN: 978-5-4475-4752-3.

FEGLEY, B.D. - TORVIK, V.I. 2012. On the role of poetic versus non-poetic features in "kindred" and diachronic poetry attribution. In: Journal of the American Society for Information Science and Technology, vol. 63, n. 11, pp. 2165-2181. ISSN: 1532-2882.

GOLOVANEVSKY, A.L. 2009. The F. Tyutchev Dictionary of Poetic Terms. Bryansk. ISBN: 5973401146. 
GRITSANOV, A.A. 2003. The Newest Dictionary of Philosophy. Minsk: Knizhny Dom. ISBN 985-428-636-3.

GROT, Ya.K. 1883. Dictionary for the poems by Derzhavin. Saint Petersburg.

KARAULOV, Yu.N. - RUZHITSKY, I.V. - GINZBURG, E.L. 2008. The Dostoyevsky Dictionary: Ideoglossary. Moscow: Azbukovnik. ISBN 978-5-91172019-3.

KARAULOV, Yu.N. 2001. The Dostoyevsky Dictionary.The Lexical Structure of the Idiolect. Moscow: Azbukovnik. ISBN: 5-88744-040-6.

KAUP, J. 2013. The Old English Judith: A Study of Poetic Style, Theological Tradition, and Anglo-Saxon Christian Concepts. Edwin Mellen Press Ltd. ISBN 10: 0773445056.

KLAUS, H.G. 2016.Committed Styles: Modernism, Politics, and Left-Wing Literature in the 1930s. In: Zeitschriftfür Anglistik und Amerikanistik, vol. 64, n. 1, pp. 109-112. ISSN: 0044-2305.

KOSHEMCHUK, T.A. 1998. Toward the question of the dialogueness of A. Tolstoy's poem "I, who raised from the darkness and dust...". In: Culture and Text, vol. 1, n. 4, pp. 204-207. ISSN: 2305-4077.

MASLIN, M.A. 2014. Russian Philosophy. Moscow: The Knigovek Book Club. ISBN: 978-5-4224-0845-0.

MILLER, S. 2015. The Oral-Written Textuality of Stichographic Poetry in the Dead Sea Scrolls. In: Dead Sea Discoveries, vol. 22, n. 2, pp. 162-188. ISSN: 0929-0761.

MURILLO, C. 2013. Style, Gender, and Fantasy in Nineteenth-Century American Women's Writing by Dorri Beam (review). American Literary Realism, vol. 46, n. 1, pp. 88-89. ISSN: 0002-9823

OLMINSKY, M.S. 1937. The Shchedrin Dictionary. Moscow: Khudozhestvennaya Literatura. ISBN 200002831416.

O'NEILL, S. 2013. Review of Explorations in Navajo Poetics by Anthony K. Webster. In: Journal of Linguistic Anthropology, vol. 23, no. 2, pp. 104-106. ISSN: 1548-1395.

OZHEGOV, S.I. - SHVEDOVA, N.Y. 2006. The Dictionary of the Russian Language. Moscow: ITI Tekhnologii. ISBN: 5-902638-10-0.

PETROV, S.M. 1961. Historical novels in the Russian literature. A teacher's handbook. Moscow: Uchpedgiz. ISBN 978-5-906976-04-8

RICHARDSON, B. 2015. Future Narratives: Theory, Poetics, and Media-Historical Moment. In: Notes and Queries, vol. 62, n. 3, pp. 484-486. ISSN 0029-3970

SOLOVYOV, V.S. 1896. Love.In the Brockhaus and Efron. In: Encyclopedic Dictionary, vol. 35, pp. 217-224.

STEWART, F. 2014a. Queer Elements: The Poetics and Politics of Antje RávicStrubel's Literary Style. In: Women in German Yearbook: Feminist Studies in German Literature \& Culture, vol. 30, pp. 44-73. ISSN: 1058-7446

STEWART, S. 2014b. Nicola Healey, Dorothy Wordsworth and Hartley Coleridge. Romanticism, vol. 20, n. 2, pp. 204-206. ISSN 1354-991x.

The BIBLE: THE MODERN RUSSIAN TRANSLATION. 2015. Moscow. Russian Biblical Society. ISBN 978-5-85524-532-5.

TOLSTOY, A.K. 1981. My bluebells. Moscow: Khudozhestvennayaliteratura.

TOLSTOY, A.K. 1984. A complete set of poems. Leningrad: SovietskyPisatel. ISBN: 978-00-1417451-0.

TOLSTOY, A.K. 1988. The night before attack. Moscow: Pravda.

TOLSTOY, A.K. 2011. Complete set of poems in one volume. Verses and poems. Moscow: Alfa-Kniga. ISBN: 978-5-9922-0820-7.

TOLSTOY, A.K. 2012.Silence descends on the cornfields. Moscow: NeksMedia. ISBN: 987-5-87107-475-6.

XLinguae, Volume 11, Issue 2, April 2018, ISSN 1337-8384, eISSN 2453-711X 
TURGENEV, I.S. 1999. A letter to the editor-in-chief of Vestnik Evropy on the death of A. Tolstoy. Moscow: Nauka. ISBN 5-02-011589-4.

TYUTCHEV, F.I. 1987. Nature is not as you imagine her. In Tyutchev, F.I. Complete set of poems. Leningrad: Sovietsky Pisatel. ISBN: 5-265

USHAKOV, D.N. 2009. The Explanatory Dictionary of the Russian Language. Moscow: AST. ISBN 978-5-17-048302-0.

VASILYEV, N.L, - ZHATKIN, D.N. 2009. The A. Delvig Dictionary. Moscow: Flinta. ISBN: 9785976508101.

VINOGRADOV, V.V. 2000. The Pushkin Dictionary. Moscow: Azbukovnik. ISBN 5-88744-026-0; ISBN 5-89285-018-8.

VINOKUR G.O. 1990.Philological studies: Linguistics and Poetics. Moscow: Nauka, ISBN 5-02-011436-7.

WANG, Y. 2014. Fashioning Voices of Their Own: Three Ming-Qing Women Writers' Uses of Qu Yuan's Persona and Poetry. In: NAN NÜ, vol. 16, n. 1, pp. 5990. ISSN: 1387-6805.

WILLIAMS, R. 2016. An Officer of Civilization: The Poetics of Michel Houellebecq of Paris. In: Nurit Buchweitz's French Studies, vol. 70, n. 2, pp. 285-286. ISSN 00161128

YEFREMOVA, T.F. 2006. The Modern Dictionary of the Russian Language. Moscow: AST. ISBN: 978-5-271-12338-2.

YELISTRATOV, V.S. 2001. The V. Shukshin Dictionary. Moscow: Azbukovnik, Russian dictionaries. ISBN: 5-937860-18-7.

YEVGENYEVA, A.P. 1999. The Small Academic Dictionary. Russian Academy of Sciences, Institute of Linguistic Studies; $4^{\text {th }}$ edition. Moscow: Russian Language. ISBN: 5-200-02672-5.

ZALIZNYAK, A.A. 2006. Ambiguity in a language and the means of its representation. Moscow: Yazykyslavianskikhkultur. ISBN: 5-9551-0114-4.

Words: 7822

Characters: 49143 (27.30 standard pages)

Assoc. prof., Oleg Voronichev, Dr. of Sci.

Assoc. prof., Natalia Mospanova, $\mathrm{PhD}$

Department of Theory and Methodology of Elementary General and Music Education

I.G. Petrovsky Bryansk State University

14 Bezhitskaya Str, Bryansk

Russia

OlegVoronichev@mail.ru

Mo_nati76@mail.ru

Assoc. prof., Natalia Atamanova, PhD

Russian Language Department

G. Petrovsky Bryansk State University

14 Bezhitskaya Str, Bryansk

Russia

atamanova2017@list.ru

Assoc. prof., Irina Strekalova, $\mathrm{PhD}$

Department of Foreign Languages

I.G. Petrovsky Bryansk State University

14 Bezhitskaya Str, Bryansk

Russia

strekiv@yandex.ru 